Issues in Nursing Research 


\title{
Issues in Nursing Research
}

\section{Papers from the 22nd annual conference of the Royal College of Nursing Research Society}

Edited on behalf of the Royal College of Nursing Research Society by

Sally J. Redfern

Lecturer in Nursing Studies

Chelsea College

University of London

Anthony R. Sisson

Area Nurse (Service Planning and Personnel)

Brent and Harrow Area Health Authority

\author{
Jean F. Walker \\ Lecturer in Nursing Studies \\ Department of Nursing Studies \\ University of Edinburgh \\ Paul A. Walsh \\ Senior Nursing Officer \\ East Berkshire Health District
}

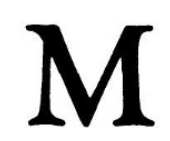


(C) The contributors 1982

Softcover reprint of the hardcover 1st edition 1982 978-0-333-32450-9

All rights reserved. No part of this publication may be reproduced or transmitted, in any form or by any means, without permission

First published 1982 by

THE MACMILLAN PRESS LTD

London and Basingstoke

Companies and representatives throughout the world

ISBN 978-1-349-06202-7 ISBN 978-1-349-06200-3 (eBook)

DOI 10.1007/978-1-349-06200-3

Typeset in Baskerville by

STYLESET LIMITED

Salisbury - Wiltshire 


\section{The contributors}

Mr Justus A. Akinsanya, Research Associate, Department of Nursing Studies, Chelsea College, University of London

Mr William J. Alagaratnam, Department of Psychiatry, Goldsmiths College, University of London

Dr Margaret F. Alexander, Lecturer, Department of Nursing Studies, University of Edinburgh

Ms Sandra Borrington, Senior Tutor, School of Nursing, Nottingham Health District

Dr Ann Bowling, Research Officer, Institute for Social Studies in Medical Care, London

Dr Lynda N. Brown, Associate Professor, School of Nursing, Vanderbilt University, Nashville, Tennessee, USA

Dr Gloria R. Burgess, Associate Professor of Nursing, School of Nursing, Southern Illinois University, USA

Miss Sheila Collins, formerly Director of Nurse Education, The London Hospital, London

Mrs Susan J. Clarke, Nursing Officer (Research), School of Medicine, University of Leicester

Miss Carolyn Crossley-Holland, Research Officer, Department of Nursing Studies, Chelsea College, University of London

Mr Bryn Davis, Deputy Director, Nursing Research Unit, University of Edinburgh
Mr Peter French, Nurse Tutor, Durham Area Health Authority Combined Schools of Nursing, Memorial Hospital, Darlington, County Durham

Dr Sheila Harrisson, Director, Health Care Research Unit, Department of Sociology and Social Policy, University of Durham

Professor Jack C. Hayward, Department of Nursing Studies, Chelsea College, University of London

Dr Lisbeth Hockey, Director, Nursing Research Unit, University of Edinburgh

Mr George G. Hoggarth, Staff Nurse, Prestwich Hospital, Manchester

Ms Kerstin Karlsson, Research Fellow, Department of Diagnostic Radiology, University Hospital, Uppsala University, Sweden

Mr John E. Maloret, Staff Nurse, Psychology Department, Moss Side Hospital, Liverpool

Mr Tadeusz Matus, Research Officer, Department of Nursing Studies, Chelsea College, University of London

Mrs Claire A. Metcalfe, DHSS Nursing Research Fellow, Department of Nursing, University of Manchester

Mrs Beryl M. Munns, Health Visitor, Basingstoke and North Hampshire Community Nursing Service

Ms Karin Ternulf-Nhylin, Research Associate, Department of Nursing, University of Umeå, Sweden 
Dr Virginia Oleson, Professor of Sociology, Department of Social and Behavioral Sciences, School of Nursing, University of California, San Francisco, USA

Dr Sally J. Redfern, Lecturer, Department of Nursing Studies, Chelsea College, University of London

Mr Colin Rees, Research Officer, Health Education Centre, South Glamorgan Health Authority, Cardiff

Miss Pamela J. Rogers, formerly Research Fellow, Department of Design Research, Royal College of Art, London

Mrs Lucianne Sawyer, Research Officer, Department of Social Science and Administration, London School of Economics and Political Science
Mr Anthony R. Sisson, Area Nurse (Service Planning and Personnel), Brent and Harrow Area Health Authority

Dr Barbara Wade, Research Fellow, Department of Social Science and Administration, London School of Economics and Political Science

Miss Jean F. Walker, Lecturer, Department of Nursing Studies, University of Edinburgh

Mr Paul A. Walsh, Senior Nursing Officer, East Berkshire Health District

Dr Mary Jane Ward, Associate Professor and Director of Research, School of Nursing, University of Colorado, Denver, USA

Miss Rosemary White, Senior Research Fellow, Department of Social Administration, University of Manchester 


\section{Contents}

The contributors

Foreword

Lisbeth Hockey

Acknowledgements

\section{Section I}

1 The Post-war Reconstruction of Nursing

Rosemary White

Section II: Nursing Education and Research

2 Whither Nursing Education? The Future of Nursing Education, where it will Start from, where it will End

3 Some Observations on Nursing Education, Research and Practice in the United States Virginia Olesen

Section III: Different Aspects of Nursing Education

Research

4 The Role of Biological Sciencesin Nursing Education Jack C. Hayward and Justus A. Akinsanya

5 Nurse Education: An Experiment in Integration of Theory and Practice in Nursing

$$
\text { Margaret F. Alexander }
$$

6 Care of the Unconscious Patient - the Teaching Given to Student Nurses Sandra Borrington

7 Academic Gaming - Assessing 'Guts' 
8 The Assessment of Training in Social Skills in Nursing, with Particular Reference to the Patient Profile Interview Bryn Davis and Karin Ternulf-Nyhlin

Section IV: Nurses

Part I: Clinical Development of Professional Nurses

9 Direct and Indirect Responsibility for Care - The Function of the Nursing Officer Tadeusz Matus and Carolyn Crossley-Holland

10 A Study of Family Practitioners: Perceived Competencies and Some of Their Implications for Nursing Education Mary Jane Ward

11 A Nurse Practitioner in Britain? Ann Bowling 178 Part II: Assertiveness and Self-Concept of Student Nurses

12 A Survey of Anxiety and Assertiveness in Student Nurses and Undergraduates

William Jeyam Alagaratnam

13 The Self-Concept of Undergraduate Nursing Students in Relation to Clinical Performance and Selected Biographical Variables

Gloria R. Burgess

Section V: The Work of Midwives and Health Visitors

14 Ante-natal Services: The Views of Midwives and Health Visitors Colin Rees

15 Patient Allocation in a Maternity Ward: A Report of Some of the Findings

Claire A. Metcalf

246

Section VI: Changing Behaviour and Attitudes in Open and Closed Settings

16 A Discussion of Aspects of Attitude Research Bryn Davis 275

17 The Effect of In-service Training on the Quality of Care in Mental Handicap 
18 The Effects of Relaxation Sessions on Violent Outbursts in a Patient Described as a Mentally Retarded Epileptic with Chronic Schizophrenia

George G. Hoggarth

294

19 Rehabilitating the Long-stay Patient from a Closed Institution to an Open Community John Maloret

300

Section VII: Marrying the Needs and Provision of Services for the Elderly

20 Reallocation of Geriatric Resources: A Proposed Scheme

Sheila Harrisson

21 Methodological Problems Related to the Assessment of Dependency: An Empirical Approach

Barbara Wade

309

22 A Review of the Factors which Have Dictated a Particular Research Strategy: The Interactive Nature of Dependency

Lucianne Sawyer

23 Care of the Elderly in the Community: Some Methodological Issues Involved in Doing a Population Survey

Susan J. Clarke

24 A Study of the Problems, Satisfactions and Needs of Elderly People Living at Home, in and around a Market Town in Hampshire

Beryl M. Munns

Section VIII: Nursing Practice: Post-Mastectomy Behaviour and Reactions to Intravenous Pyelography

25 Behavioural Changes Post-mastectomy

Lynda N. Brown

26 Effects of Information to Patients Undergoing Intravenous Pyelography. Part I: Exploratory Study

Kerstin Karlsson

Section IX: Design and Evaluation of the Physical Environment for Patient Care

27 Patient-Nurse Contact in Wards of Different Design Jean F. Walker 
x Contents

28 The Design, Development and Evaluation of a Portable Commode Pamela J. Rogers 412

Section X

29 Some Methodological Issues in Nursing Research

Lisbeth Hockey 423 


\section{Foreword}

\section{LISBETH HOCKEY}

As Honorary Chairman of the Research Society of the Royal College of Nursing it is my pleasure and privilege to introduce this unique publication which consists of papers from the 22nd Annual Conference. Although the Research Society holds annual conferences, this is the first time that the papers have been made available in book form for general sale. The editors have undertaken a difficult task in editing the proceedings and their hard work is gratefully acknowledged. The book covers a wide spectrum of nursing research with contributions from experienced as well as novice researchers. There can hardly be a branch or specialty in nursing which is not represented and this growth of research activity is heartening. Nurse historians, educators, administrators and planners, as well as practitioners, will find papers of relevance to their field of activity; moreover, most professional specialties such as midwifery, health visiting, and geriatric, general, mental handicap and psychiatric nursing, are included. The research methodologists will not be disappointed as most authors have given the level of emphasis to the design, method and analysis of their study which is appropriate for a research conference. Indeed, several papers have their main focus on methodological issues.

Unfortunately, it was impossible to record the discussions which followed each paper; they formed a most important and valuable part of the conference. It was equally impossible to reproduce in cold print the conference atmosphere, the informal debates, the excitement and the esprit de corps of a group of people who had come from many parts of the UK as well as several countries on both sides of the Atlantic in order to engage in scientific debate relating to the critical analysis of our profession. 


\section{xii Foreword}

This book bears witness to an increasing professional maturity and augurs well for the future. I hope it will find an eager and enthusiastic readership. It is the coming together of research and nursing which must be our goal. 


\section{Acknowledgements}

The contribution of the exhibitors, chairmen and sponsors of the conference is most gratefully acknowledged. Without their help the conference could not have taken place and this volume would not have been published. They are listed below.

We are grateful to the following for chairing sessions at the 22nd annual conference of the RCN Research Society:

Chris Armstrong-Esther, Professor of Nursing Studies, University of Surrey

Dorothy Baker, Senior Lecturer in Nursing, University of Manchester

Rosemary Crow, Director, Nursing Practice Research Unit, Northwick Park Hospital, Harrow, Middlesex

Trevor Clay, General Secretary Designate, Royal College of Nursing

Alison Dunn, Editor, Nursing Times

Jack Hayward, Professor of Nursing Studies, Chelsea College, University of London

Lisbeth Hockey, Director, Nursing Research Unit, University of Edinburgh

Jennifer Hunt, Director of Nursing Research, Royal Marsden Hospital

David Ingram, Vice-Chancellor, University of Kent

Charlotte Kratz, Chairman of the RCN Society of Primary Health Care

Karen Luker, Lecturer in Nursing Studies, University of Manchester

Sylvia Lelean, Principal Nursing Officer (Research), Department of Health and Social Security, London

Marion Morgan, President of the Royal College of Nursing Doreen Norton, Nursing Research Liaison Officer, South West Thames Regional Health Authority 
xiv Acknowledgements

David Rye, Director of Professional Activities, Royal College of Nursing

We are very grateful for the generous donations received from the following:

Blackwell Scientific Publications Ltd

Boots Co Ltd

Churchill Livingstone

Croom Helm Ltd

Dettol Products

Dillons University Bookshop

Imperial Chemical Industries Ltd

Johnson and Johnson

King Edward's Hospital Fund for London

Lederle Laboratories

Marks and Spencers Ltd

The Macmillan Press Ltd

C. V. Mosby and Co

Nestles Co Ltd

Pfizer Ltd

Smith and Nephew Ltd

The Vice-Chancellor of the University of Kent (Dr Ingram) 